ISSN 1392-3196 / e-ISSN 2335-8947

Zemdirbyste-Agriculture, vol. 108, No. 1 (2021), p. 19-26

DOI 10.13080/z-a.2021.108.003

\title{
Biofuel ash granules as a source of soil and plant nutrients
}

\author{
Kristina BUNEVIČIENĖ, Donata DRAPANAUSKAITĖ, Romas MAŽEIKA, \\ Vita TILVIKIENE் \\ Lithuanian Research Centre for Agriculture and Forestry \\ Instituto 1, Akademija, Kèdainiai distr., Lithuania \\ E-mail: kristina.buneviciene@lammc.lt
}

\begin{abstract}
Biofuel production and bioenergy generation play significant role in the energy self-sufficiency of the countries, climate change mitigation, but also increase the accumulation of waste. The main waste of biomass burning process is ash and lime kiln dust. This study hypothesized that those materials could be potential fertilisers for agricultural crops. The aim of the research was to evaluate the uptake of nutrients in spring barley grain and straw when using granulated ash and bulk biofuel ash in an open-air pot experiment. The results obtained in pot experiment showed that using granulated ash an increase of total potassium $\left(\mathrm{K}_{\text {to }}\right)$ content $\left(21.5-28.0 \mathrm{~g} \mathrm{~kg}^{-1}\right)$ in spring barley straw was observed in 2018, while in 2017 the amount of $\mathrm{K}_{\text {tot }}$ did not change significantly. Calcium concentration in straw increased significantly in the second year of the experiment. No significant changes in the content of heavy metals $(\mathrm{Cd}, \mathrm{Pb}, \mathrm{Ni}$ and $\mathrm{Cr})$ were observed in the soil. The concentrations of these metals did not exceed the permissible levels. Due to the high $\mathrm{Cu}$ and $\mathrm{Zn}$ concentration in biofuel ash, the content of these microelements increased in the soil. Overall, the content of major nutrients, microelements and heavy metals increased with increasing biofuel ash content in granules: in spring barley grain, $\mathrm{Cd}\left(0.003-0.030 \mathrm{mg} \mathrm{kg}^{-1}\right)$ and $\mathrm{Zn}\left(4.58-22.5 \mathrm{mg} \mathrm{kg}^{-1}\right)$ were detected, in straw $-\mathrm{Zn}$ and $\mathrm{Cu}$.
\end{abstract}

Key words: biofuel, ash granules, lime kiln dust, nutrients, heavy metals.

\section{Introduction}

Biofuel ash is not just waste. It can also be used as a raw material, because everything that comes from nature has to be returned to nature. Therefore, changes in processes in the ecosystem take place cyclically. It all starts with biomass: biofuels are obtained from biomass and waste, which are then burned.

The study is relevant to the temperate broadleaf forest zone, in which Lithuania is located. The area is rich in forest resources that allow the use of biofuel for heat and electricity production. For the southern part of Sweden and the northern part of Germany and Poland, one of the uses of biofuel ash is to process it into granular fertiliser. The use of these products requires higher soil moisture, which is typical of the temperate broadleaf forest zone. During combustion, about 5-10\% of biofuel mass is returned to the environment in the form of ash (Lamers et al., 2018). Part of the resulting ash is stored in landfills; the other part is spread on the fields. Meanwhile, the third most relevant option at the moment is fertilisation products made from biofuel ash, which enrich the soil with phosphorus $(\mathrm{P})$, potassium $(\mathrm{K})$, calcium $(\mathrm{Ca})$, magnesium $(\mathrm{Mg})$ and other macroand microelements.
The amount of generated biofuel ash depends on the intensity of biomass use for bioenergy and differs between countries (Lamers et al., 2018). Biofuel ash is a heterogeneous and complex mixture of crystalline, amorphous and inorganic minerals with organic substances (Vassilev et al., 2013). Biofuel ash usually contains large amount of $\mathrm{Ca}, \mathrm{K}, \mathrm{Mg}$ and $\mathrm{P}$, which are necessary for plant growth and productivity. In addition, plants need microelements manganese $(\mathrm{Mn})$ and iron $(\mathrm{Fe})$, which are also present in biofuel ash (Dimkpa, Bindraban, 2016). In general, biofuel ash contains lower concentration of $\mathrm{Ca}$ and $\mathrm{Mg}$ compared to the mineral fertilisers usually used agriculture (Cole et al., 2016).

Currently, the largest amount of biofuel ash is stored in landfills (Pesonen et al., 2017). In order to reduce the negative effect on the environment and to increase the economic value of the biomass burning process, we need to find a wider use of such waste. Maschowki et al. (2016) indicated that wood ash can be used as supplement to mineral fertilisers or used as separate fertiliser. In particular, biofuel ash contains most of the major nutrients, which are vital for agricultural crops - their development, growth, productivity and quality (Freire et al., 2015).

Please use the following format when citing the article:

Bunevičienė K., Drapanauskaitė D., Mažeika R., Tilvikienè V. 2021. Biofuel ash granules as a source of soil and plant nutrients. Zemdirbyste-Agriculture, 108 (1): 19-26. DOI 10.13080/z-a.2021.108.003 
Nevertheless, there are many questions about ash quality improvement and technological management (Dwivedi, Jain, 2014). It should be noted that the use of granulated ash for crop fertilisation could be attractive due to its economic benefits (Rasmusson et al., 2013).

The ash is less dense and lighter compared to the soil; therefore, it gets into the top layers of the soil and accumulates (Kafodya, Okonta, 2018). Due to the water and wind, the smallest biofuel ash particles may be released into the atmosphere (Kuppusamy et al., 2016). However, this problem has not only negative environmental impact but also reduces the fertility of ash. One of the most effective solutions to this problem is to make ash granules by inserting cement material and changing the physical state of dusty powders (Bowden-Green, Briens, 2016). The granulation of ash has been found to be cost-effective and environmentally friendly (Vaatainen et al., 2011). Arulrajah et al. (2017) found that lime kiln dust could be a potential material for the improvement of ash granules, but due to the limited information on the quality and the effectiveness on crop growth such granules are poorly used (Al-Homidy et al., 2017).

Chemical composition of ash depends on the quality of burned biomass (Yao et al., 2014). Due to the high concentration of heavy metals in biofuel ash, it can be used as a major source of environmental pollution (Patra et al., 2012). Researchers have found that heavy metals such as $\mathrm{Cd}, \mathrm{Pb}, \mathrm{Ni}$ and $\mathrm{Cr}$ can pose a threat to the ecosystem even at low concentration levels (Pujilestari et al., 2017). On the other hand, it is expected that the concentration of these elements and their release may be changed by making ash granules with lime kiln dust.

This research hypothesizes that the ash granules can improve soil fertility and replace mineral fertilisers. The interplay between the physicochemical properties of granulated ash and nutrient and heavy metal release properties is thus elucidated.

The aim of the present research was to evaluate the influence of bulk biofuel ash and biofuel ash granules on plant quality and the influence on soil nutrient balance and changes in heavy metal concentration.

\section{Materials and methods}

Nutrient recycling and reuse from biomass thermochemical combustion are presented in Figure 1.

Materials and reagents. Wood biofuel ash and lime kiln dust were obtained from the working biomass power plants in Lithuania. Bulk biofuel ash was produced by a thermochemical process (burning) of wood pellets.

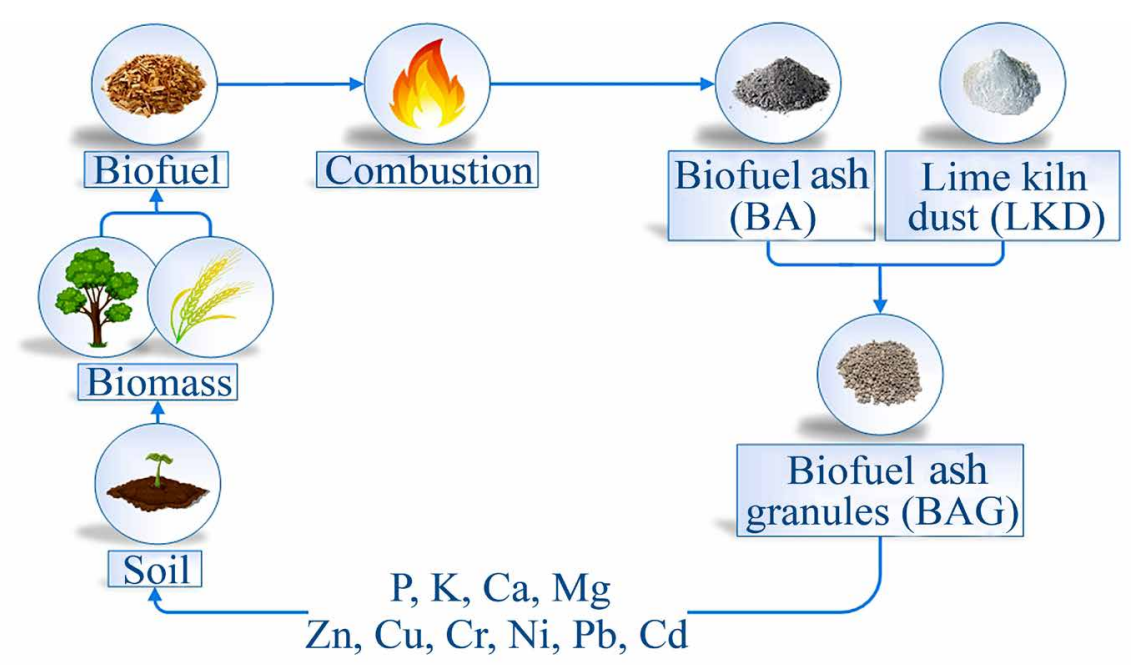

Figure 1. Possible recycling and reuse of nutrients from biomass thermochemical combustion ash to replenish the soil without introducing significant amounts of heavy metals

Granulation of biofuel ash and lime kiln dust. The biofuel ash granules (BAG) were produced under laboratory conditions. Both materials, bulk biofuel ash and lime kiln dust, were mixed using a ribbon blade agitator. A small amount $(\sim 12 \%)$ of water was added to the dry materials until small aggregates started to form a paste. The paste was granulated using a disc pelletizer. It was comprised of an interior disk, which was rotated at about 20 revolutions per minute in a plane inclined at 60 degrees. After granulation, the biofuel ash granules were dried at room temperature in a laboratory fume hood for 24 hours (Buneviciene et al., 2020).

The experiment included the following treatments: 1) control; 2) biofuel ash (BA); 3) the granulated ash with $30 \%$ ash in granule (BAG30); 4) the granulated ash with 50\% ash in granule (BAG50) and 5) the granulated ash with $70 \%$ ash in granule (BAG70). The other part consisted of lime kiln dust, accordingly $70 \%, 50 \%$ and $30 \%$. These granules were used in the pot experiment in 2017-2018. The availability of major nutrients present in bulk biofuel ash and granulated ash to spring barley grain and straw was assessed.

Chemical composition analysis. The samples of bulk biofuel ash and granulated ash were ground, sieved and extracted with aqua regia and then analysed for the content of heavy metals with an atomic emission spectrophotometer (Perkin Elmer, USA). Atomic absorption spectroscopy (Perkin Elmer) was used to determine the content of total calcium $(\mathrm{Ca})$ and total magnesium (Mg). Flame photometer (Sherwood, UK) was used to measure total potassium $(\mathrm{K})$, and UV spectrophotometer (Shimadzu, Germany) was applied to estimate total phosphorus (P).

Pot experiment. The soil used for the pot experiment was Eutri-Hypostagnic Albeluvisol (WRB, 2014). According to the texture, this soil is classified as loam. Chemical composition of the experimental soil is presented in Table 1. 
Table 1. Soil agrochemical characteristics: content of major nutrients, heavy metals and acidity

\begin{tabular}{|c|c|c|c|c|}
\hline \multirow{2}{*}{$\begin{array}{c}\text { Major nutrients } \\
\text { and heavy metals }\end{array}$} & \multirow{2}{*}{ Measurement unit } & \multicolumn{2}{|c|}{ Concentration } & \multirow{2}{*}{$\begin{array}{l}\text { Max allowable limits } \\
\text { (HN 60:2004) }\end{array}$} \\
\hline & & 2017 & 2018 & \\
\hline Mobile $\mathrm{K}_{2} \mathrm{O}$ & \multirow{6}{*}{$\%$} & $0.015 \pm 0.0006$ & $0.017 \pm 0.0016$ & - \\
\hline Mobile $\mathrm{P}_{2}^{2} \mathrm{O}_{5}$ & & $0.038 \pm 0.0017$ & $0.036 \pm 0.0023$ & - \\
\hline Mobile $\mathrm{Ca}^{5}$ & & $0.10 \pm 0.003$ & $0.092 \pm 0.0042$ & - \\
\hline Mobile Mg & & $0.010 \pm 0.0004$ & $0.011 \pm 0.0001$ & - \\
\hline Organic C & & $1.37 \pm 0.015$ & $1.41 \pm 0.010$ & - \\
\hline Total N & & $0.123 \pm 0.0006$ & $0.125 \pm 0.0006$ & \\
\hline $\mathrm{Cd}$ & \multirow{6}{*}{$\mathrm{mg} \mathrm{kg}^{-1}$} & $0.060 \pm 0.0020$ & $0.052 \pm 0.0075$ & 3 \\
\hline $\mathrm{Pb}$ & & $8.75 \pm 0.029$ & $9.84 \pm 0.099$ & 100 \\
\hline $\mathrm{Ni}$ & & $5.40 \pm 0.707$ & $5.75 \pm 0.280$ & 75 \\
\hline $\mathrm{Cr}$ & & $9.40 \pm 0.025$ & $9.98 \pm 0.108$ & 100 \\
\hline $\mathrm{Cu}$ & & $3.47 \pm 0.092$ & $4.30 \pm 0.030$ & 100 \\
\hline $\mathrm{Zn}$ & & $17.9 \pm 0.06$ & $21.0 \pm 0.80$ & 300 \\
\hline $\mathrm{pH}_{\mathrm{KCl}}$ & & $5.5 \pm 0.06$ & $5.5 \pm 0.06$ & - \\
\hline
\end{tabular}

Note. Concentration means of 3 replications \pm standard deviation.

The experiment was carried out for two years (2017 and 2018) at the Lithuanian Research Centre for Agriculture and Forestry Agrochemical Research Laboratory in Kaunas. The pot experiment was conducted in the open-air testing site (Fig. 2). The experimental pots were $10 \mathrm{~L}$ plastic containers: $9 \mathrm{~L}$ of soil was placed in each pot, and $1 \mathrm{~L}$ of soil was mixed with equivalent to $3 \mathrm{t} \mathrm{ha}^{-1}$ of each fertiliser material. The mixture was

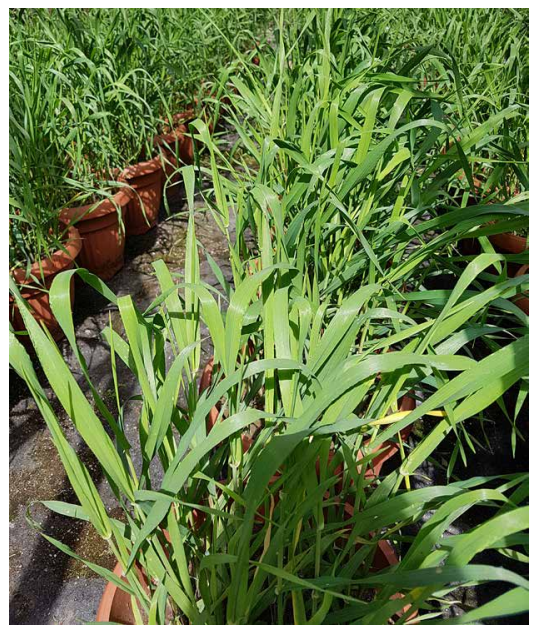

deposited above the pure soil. Twenty seeds of the spring barley (Hordeum vulgare L.) cultivar 'Ema DS' were sown at a depth of $1 \mathrm{~cm}$ at equal distances in each pot (Buneviciene et al., 2020). The experiment was laid out in a randomised design with 4 replicates. No mineral fertilisers were added. The pots were kept under natural climate conditions and watered manually when needed.

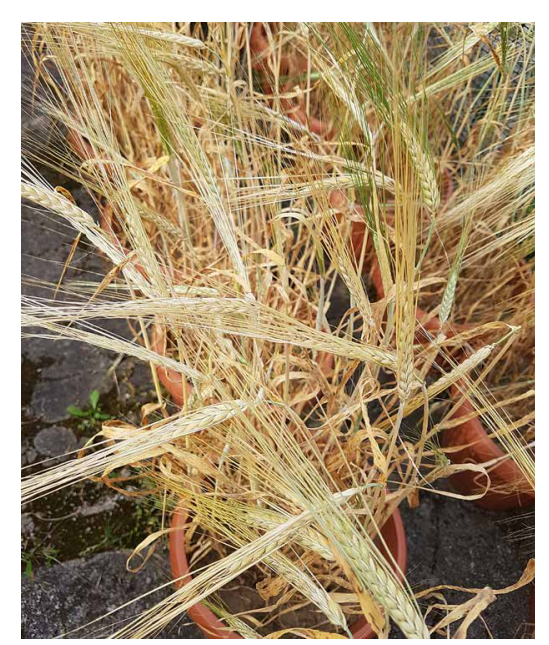

Figure 2. Spring barley growing in an open-air pot experiment

The content of mobile $\mathrm{K}_{2} \mathrm{O}, \mathrm{P}_{2} \mathrm{O}_{5}, \mathrm{Ca}$ and $\mathrm{Mg}$ in the soil was determined using ammonium lactate-acetic acid extraction by the Egner, Riehm and Domingo (A-L) method. Inductively coupled plasma-mass spectrometry (ICP-MS) was used to determine the concentration of major nutrients, microelements and heavy metals in spring barley grain and straw and heavy metals in soil. The determination of soil acidity $(\mathrm{pH})$ was made in $1: 5\left(\mathrm{vol} \mathrm{vol}^{-1}\right)$ soil suspension in the $1 \mathrm{M} \mathrm{KCl}$ solution (Buneviciene et al., 2020).

Meteorological conditions. The average air temperatures during the growing season (May-August) of 2017 and 2018 were $13.8^{\circ} \mathrm{C}$ and $18.5^{\circ} \mathrm{C}$, while the long-term average was $15.5^{\circ} \mathrm{C}$. The total precipitation recorded in 2018 was higher and reached $279.4 \mathrm{~mm}$ compared to the first year of the experiment $(225.3 \mathrm{~mm})$ in May-August (Lithuanian Hydrometeorological Service under the Ministry of Environment data, http:// www.meteo.lt/). In both experimental years, the amount of precipitation in May and August was lower compared to the long-term (1947-2018) average for these months.
July of 2018 was a very wet period. The amount of precipitation totalled as much as $137.5 \mathrm{~mm}$, and it was half of the amount of precipitation that fell during the growing period, as shown in Figure 3.

Statistical analysis. The values of the results and the standard deviation were calculated using the computer program Microsoft Office Excel. A one-way analysis of variance (ANOVA) was used to evaluate the data of the spring barley grain and straw properties. Means were compared using Duncan's test at $p<0.01$ the software package $S A S$, version 9.3 (SAS Institute, USA) was used for statistical analysis. The correlation-regression analysis of data was used to determine the relationship between the variables at $95 \%$ and $99 \%$ probability level $(p<0.05$ and $p<0.01)$.

\section{Results and discussion}

Chemical composition of bulk biofuel ash (BA), lime kiln dust and granulated ash. Table 2 shows the chemical composition of bulk BA and lime kiln dust 

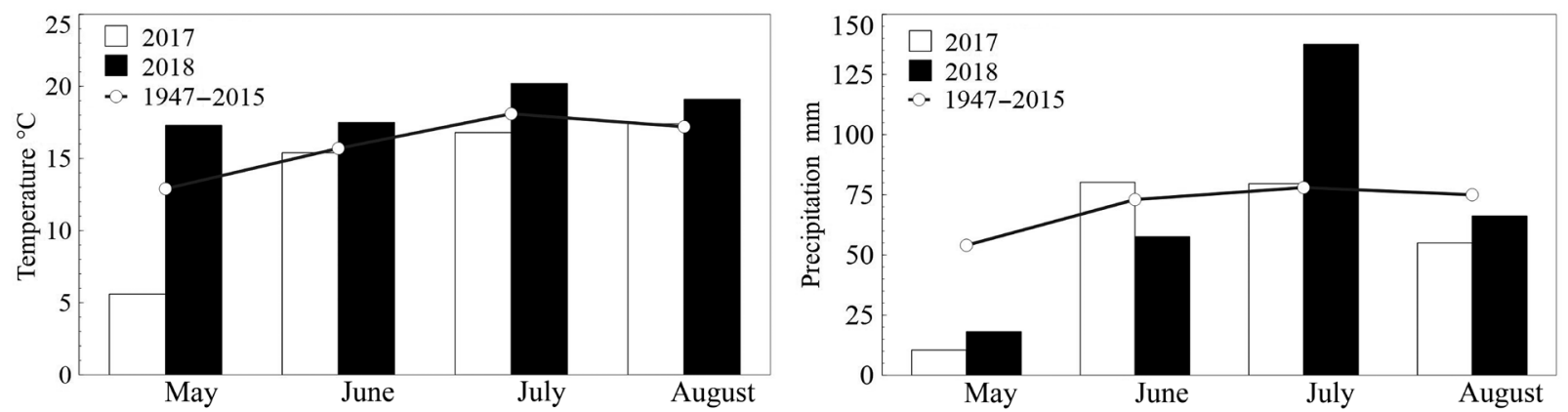

Figure 3. Temperature and precipitation during the experimental period of 2017-2018 and long-term average in Kaunas

Table 2. Chemical composition of bulk biofuel ash, lime kiln dust and granular fertilisers

\begin{tabular}{cccccc}
\hline \multirow{2}{*}{$\begin{array}{c}\text { Major } \\
\text { nutrients }\end{array}$} & biofuel ash & lime kiln dust & BAG30 & BAG50 & BAG70 \\
\cline { 2 - 5 } & \multicolumn{5}{c}{ Fertilisers } \\
\cline { 2 - 5 } $\mathrm{Ca}$ & $30.2 \pm 1.24$ & $41.2 \pm 0.35$ & $34.92 \pm 0.42$ & $33.3 \pm 0.57$ & $26.7 \pm 0.60$ \\
$\mathrm{Al}$ & $9.42 \pm 0.578$ & $0.78 \pm 0.041$ & $0.752 \pm 0.054$ & $0.89 \pm 0.067$ & $0.93 \pm 0.058$ \\
$\mathrm{~S}$ & $5.87 \pm 0.414$ & $1.00 \pm 0.145$ & $0.672 \pm 0.114$ & $0.62 \pm 0.124$ & $0.59 \pm 0.132$ \\
$\mathrm{~K}$ & $5.70 \pm 0.189$ & $0.43 \pm 0.084$ & $1.29 \pm 0.146$ & $2.13 \pm 0.158$ & $3.51 \pm 0.197$ \\
$\mathrm{Fe}$ & $4.73 \pm 0.271$ & $0.51 \pm 0.137$ & $0.402 \pm 0.115$ & $0.48 \pm 0.134$ & $0.47 \pm 0.138$ \\
$\mathrm{P}$ & $3.86 \pm 0.256$ & $0.12 \pm 0.019$ & $0.772 \pm 0.067$ & $1.51 \pm 0.089$ & $2.39 \pm 0.169$ \\
$\mathrm{Mg}$ & $2.43 \pm 0.142$ & $0.87 \pm 0.014$ & $0.922 \pm 0.231$ & $1.44 \pm 0.187$ & $1.41 \pm 0.181$ \\
\hline
\end{tabular}

Note. Concentration means of 3 replications \pm standard deviation.

powder. Both are comprised chiefly of calcium cations $\left(\mathrm{Ca}^{2+}\right)$ containing chemical compounds. The composition of Ca ranged from $\sim 50 \%$ to $\sim 95 \%$ of major nutrients by weight.

Usually, lime kiln dust contains high amount of $\mathrm{Ca}$, which depends on whether high $\mathrm{Ca}$ lime or dolomitic lime is processed (Drapanauskaite et al., 2020). In most cases, the concentration of $\mathrm{CaO}$ in lime kiln dust varied from $31 \%$ to $55 \%$, and the concentrations of other elements was significantly lower: $0.5-25 \% \mathrm{MgO}, 1.7-$ 9.9\% $\mathrm{SiO}_{2}, 0.03-0.22 \% \mathrm{~K}_{2} \mathrm{O}$ and $0.7-4.1 \% \mathrm{Al}_{2} \mathrm{O}_{3}$ (ElAttar et al., 2017).

In biofuel ash $\mathrm{P}$ content was $\sim 3.8 \%$ (Table 2 ). $\mathrm{P}$ is one of the main nutrients needed for grain formation and grain yield increase. $\mathrm{Al}$ and $\mathrm{Fe}$ were present in biofuel ash and lime kiln dust. Muhammad et al. (2019) found that water soluble aluminium $\left(\mathrm{Al}^{3+}\right)$ can have toxic effect on the plants directly or by binding $\mathrm{P}$ into insoluble compounds. However, the damage is dangerous only if soil $\mathrm{pH}$ is $<5.5$ (Kryzevicius et al., 2019). The presence of $\mathrm{Fe}$ in the tested fertilisers was promising, as it is one of the main nutrients that is required for effective plant growth and reproduction (Kobayashi, Nishizawa, 2012). However, Fe availability to plants is very limited in alkaline soils due to low plant adsorption abilities (Soares et al., 2019). The concentration of major nutrients in granulated ash depended on the amount of lime kiln dust added to the granules (Table 2). Granular fertiliser BAG30 contained $34.9 \%$ of Ca, BAG50 - 33.3\% and in BAG70 Ca decreased to $26.7 \%$. The ash granules were not homogeneous; therefore, this contributed to the uneven release of major nutrients from the soil.

The main microelements and heavy metals, which were found in the tested fertilisers, were: cadmium $(\mathrm{Cd})$, lead $(\mathrm{Pb})$, nickel $(\mathrm{Ni})$, chromium $(\mathrm{Cr})$, copper $(\mathrm{Cu})$ and zinc ( $\mathrm{Zn}$ ) (Table 3 ). $\mathrm{Zn}$ and $\mathrm{Cu}$ are microelements, when their concentrations in the soil are low (Aissaoui, Barkat, 2018). Notably, BA contained about 14 times higher content of microelements and heavy metals compared to the lime kiln dust. In bulk biofuel ash, the $\mathrm{Zn}$ content alone was $\sim 700 \mathrm{mg} \mathrm{kg}^{-1}$ and $\mathrm{Cu}-\sim 120 \mathrm{mg} \mathrm{kg}^{-1}$ (Table 3).

The use of new biomaterials for crop fertilisation is always dangerous due to their ability to accumulate high content of heavy metals in the soil. In our experiment, granulated ash (BAG30) had the lowest effect on the accumulation of microelements and heavy metals in the soil (Table 3).

Table 3. The concentration of microelements $(\mathrm{Zn}$ and $\mathrm{Cu})$ and heavy metals $(\mathrm{Cr}, \mathrm{Ni}, \mathrm{Pb}$ and $\mathrm{Cd})$ in biofuel ash and lime kiln dust, and the cumulative amount of microelements and heavy metals in the soil after application of $3 \mathrm{t}^{-1}$ of fertilisers

\begin{tabular}{|c|c|c|c|c|c|c|c|}
\hline \multirow{3}{*}{$\begin{array}{l}\text { Microelements } \\
\text { and } \\
\text { heavy metals }\end{array}$} & \multicolumn{6}{|c|}{ Fertilisers } & \multirow{2}{*}{$\begin{array}{c}\text { Max } \\
\text { allowable } \\
\text { limits* }\end{array}$} \\
\hline & biofuel ash & lime kiln dust & biofuel ash & BAG30 & BAG50 & BAG70 & \\
\hline & \multicolumn{2}{|c|}{$\mathrm{mg} \mathrm{kg}^{-1}$} & \multicolumn{4}{|c|}{$\mathrm{kg} \mathrm{ha}^{-1}$} & \\
\hline $\mathrm{Zn}$ & $703 \pm 24.1$ & $21.1 \pm 6.51$ & 2.11 & 0.42 & 0.89 & 0.95 & 140 \\
\hline $\mathrm{Cu}$ & $123 \pm 1.2$ & $10.4 \pm 0.14$ & 0.37 & 0.068 & 0.12 & 0.15 & 75 \\
\hline $\mathrm{Cr}$ & $28.3 \pm 1.11$ & $12.1 \pm 2.19$ & 0.091 & 0.065 & 0.067 & 0.069 & - \\
\hline $\mathrm{Ni}$ & $8.13 \pm 0.321$ & $8.60 \pm 0.283$ & 0.024 & 0.022 & 0.024 & 0.026 & 21 \\
\hline $\mathrm{Pb}$ & $9.07 \pm 3.114$ & $9.65 \pm 3.323$ & 0.027 & 0.021 & 0.023 & 0.020 & 15 \\
\hline $\mathrm{Cd}$ & $4.83 \pm 0.091$ & $0.56 \pm 0.014$ & 0.016 & 0.004 & 0.008 & 0.008 & 9 \\
\hline
\end{tabular}

Note. ${ }^{*}$ - according to United States Environmental Protection Agency (EPA, 1999); concentration means of 3 replications \pm standard deviation. 
Release of microelements, heavy metals and major nutrients from fertilisers. As shown in Figure 4, the content of microelements and heavy metals increased in the soil compared to the pots, where no fertilisers were added (control). However, the concentration of microelements and heavy metals in the soil during the two-year experiment was significantly lower than any regulatory limits (HN 60:2004). When using BAG, it was found that higher BA content in the granule proportionally increased metal concentration in the soil, i.e. with increasing ash content in the pellets the heavy metal concentration in the soil increased (Fig. 4).
Rodriguez et al. (2019) also indicated that wood ash is not very dangerous in terms of heavy metal contamination. Migration of heavy metals and microelements is usually limited due to their low water solubility; therefore, they are usually found in the topsoil. The availability of microelements (as well as heavy metals) to plants is influenced by many chemical processes; however, the main ones are adsorption and desorption, which influence their bioavailability and mobility. In our experiment, biofuel ash was rich in microelements ( $\mathrm{Zn}$ and $\mathrm{Cu}$ ) (Table 3); therefore, the content of these elements increased in the soil (Fig. 4). In general, the

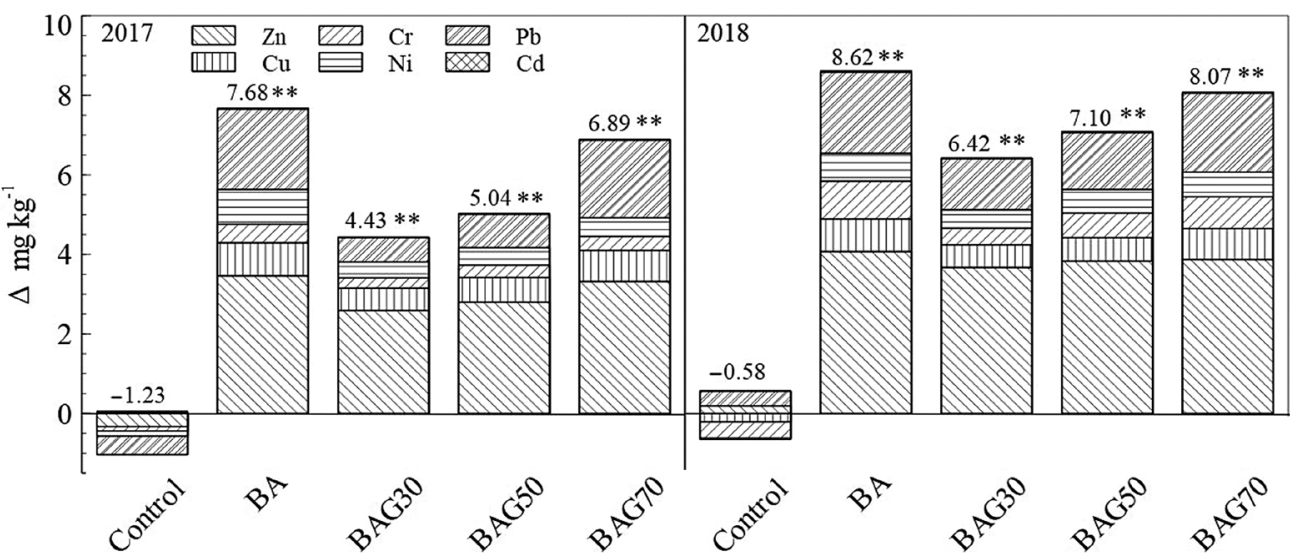

** - significant differences between treatments in comparison with the control at $p<0.01$; BA - biofuel ash

Figure 4. The content of microelements $(\mathrm{Zn}$ and $\mathrm{Cu})$ and heavy metals $(\mathrm{Cr}, \mathrm{Ni}, \mathrm{Pb}$ and $\mathrm{Cd})$ in the soil after application of $3 \mathrm{t} \mathrm{ha}^{-1}$ of fertilisers in 2017 and 2018

concentrations of heavy metals and microelements increased linearly, depending on the amount of BA in the granule ( $r=0.96$ in 2017 and $r=0.99$ in 2018).

Agricultural crops accumulate many major nutrients that are removed from the soil. Therefore, the nutrient balance of different agricultural management systems has to be evaluated to preserve soil resources and increase plant productivity (Masilionytė, Maikštėnienè,
2016). The positive nutrient balance ensures plant fertility and maintains soil productivity. Nutrient balance accounts for the nutrient accumulation in crop and leaching losses (Adomaitis et al., 2013).

As the main major nutrients in BA were $\mathrm{P}, \mathrm{K}, \mathrm{Ca}$ and $\mathrm{Mg}$, their two-year balance was calculated and shown in Figure 5. It is noteworthy that nutrient balance in the soil is highly influenced by meteorological conditions.
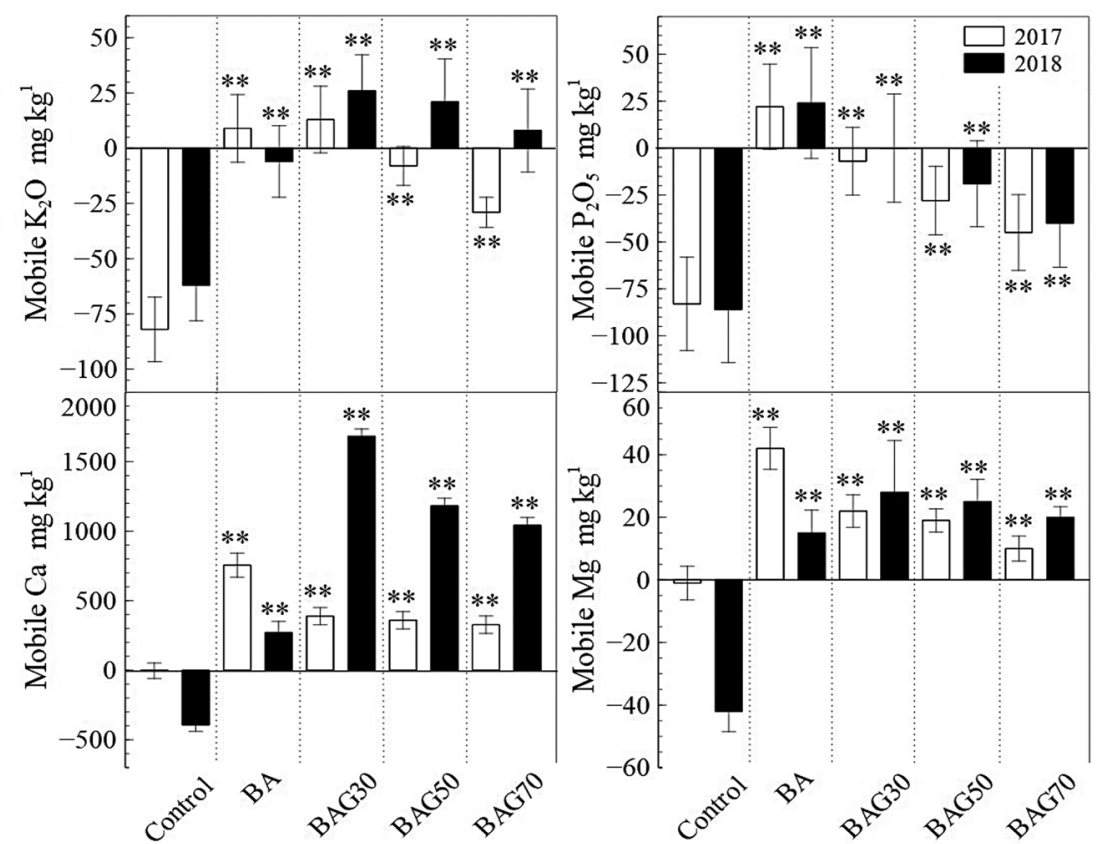

** - significant differences between the treatments in comparison with the control at $p<0.01$; BA - biofuel ash

Figure 5. The balance of major nutrients in the soil after application of $3 \mathrm{t} \mathrm{ha}^{-1}$ of fertilisers in 2017 and 2018 
Overall, $\mathrm{P}$ balance was negative in all treatments except for the treatment with BA in both experimental years. This is consistent with the increase in mobile $\mathrm{P}_{2} \mathrm{O}_{5}$ content in the soil when using BA. This suggests that BA alone was sufficient to supply enough $P$ nutrients for crop growth or that the soil was already sufficiently $\mathrm{P}$ rich. While within the error margin, change of $\mathrm{K}$ content was also largely positive when using BA and BAG, but starkly negative under control treatment. $\mathrm{Ca}$ balance was positive in all the cases tested except for the control conditions (Fig. 5). Ca is much more efficiently released from lime kiln dust. Therefore, the highest amount of $\mathrm{Ca}$ was released when BAG30 granules were used, as they contained the highest content of $\mathrm{Ca}$. The soil was particularly rich in $\mathrm{Ca}$ in $2018-\sim 3$ to 4 times more than in 2017. The content $\mathrm{Mg}$ was also higher in 2018, and

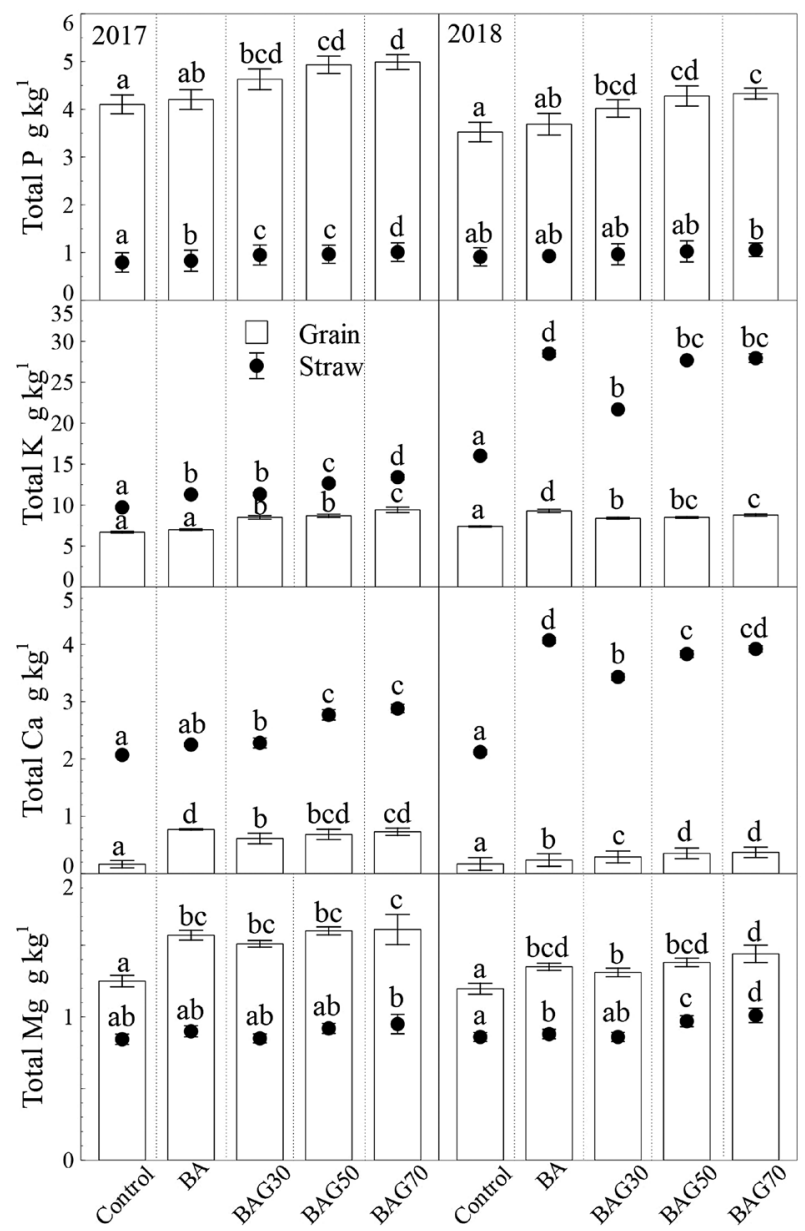

the balance was positive. Precipitation can be beneficial for the release of major nutrients $(\mathrm{K}, \mathrm{P}, \mathrm{Ca}$ and $\mathrm{Mg})$ from BAG and transport of these nutrients into the soil, where the main roots are; however, excessive rain can increase leaching potential of major nutrients.

Chemical composition of major nutrients, microelements and heavy metals. The study further analysed the concentrations of major nutrients (K, P, Ca and $\mathrm{Mg}$ ) in spring barley grain and straw. The application of BA, BAG30 and BAG50 fertilisers did not have a statistically significant effect on the concentrations of $\mathrm{P}$ in spring barley straw in 2018. A statistically significant effect was observed in the spring barley grain: $\mathrm{K}$ concentration varied within a small range of 6.68 $9.42 \mathrm{~g} \mathrm{~kg}^{-1}$ in 2017 and $7.37-9.29 \mathrm{~g} \mathrm{~kg}^{-1}$ in 2018 (Fig. 6).

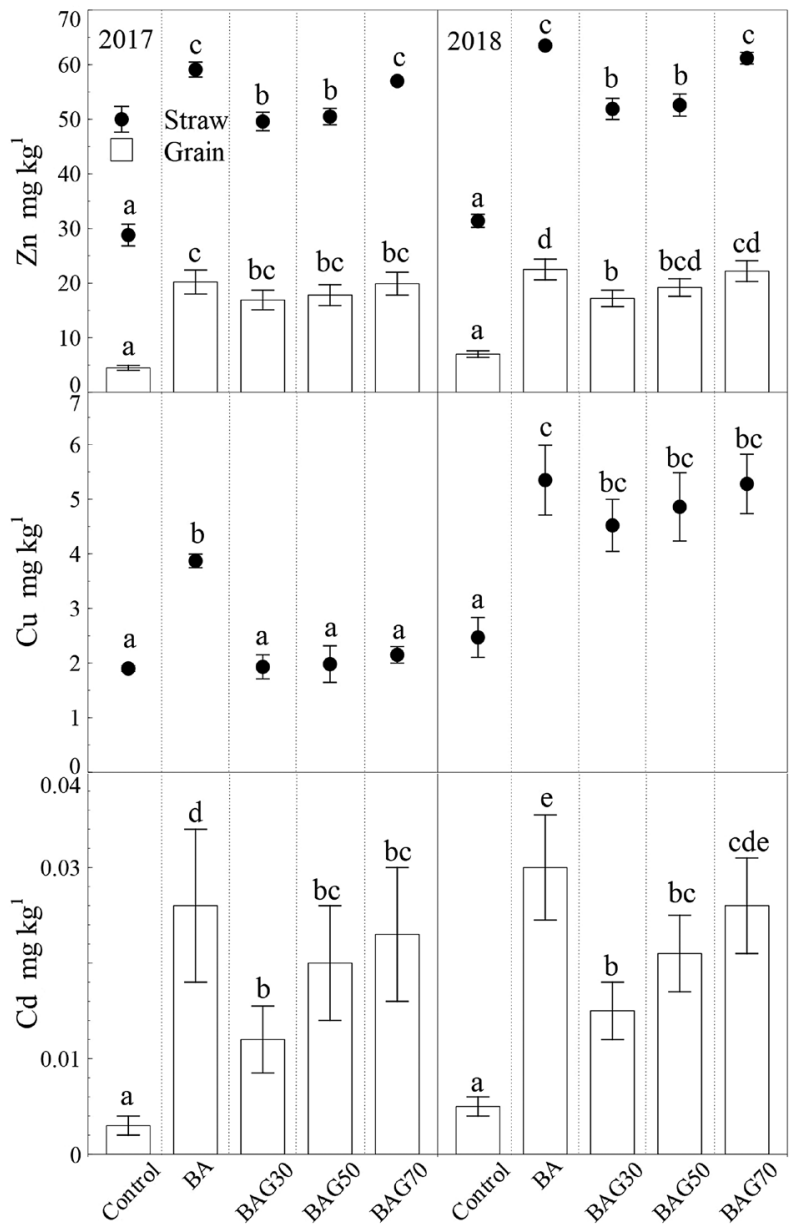

Note. Results marked by the same letter are not significantly different at $p<0.05$.

Figure 6. The change in major nutrients $(\mathrm{P}, \mathrm{K}, \mathrm{Ca}$ and $\mathrm{Mg})$, microelements $(\mathrm{Zn}$ and $\mathrm{Cu})$ and heavy metal $(\mathrm{Cd})$ concentration in spring barley grain and straw as influenced by fertilisation with biofuel ash (BA) and granular fertilisers (BAG30, BAG50 and BAG70)

Meanwhile, BAG had a statistically significant effect on $\mathrm{K}$ content in spring barley straw in 2018. Compared to the control, the concentration of $\mathrm{K}$ increase accounted for $\sim 75 \%$ with BA, BAG50 and BAG70 fertilisers. This suggests that the straw absorbed most of $\mathrm{K}$ previously contained in BA and BAG. The concentration of $\mathrm{Ca}$ increased significantly in the straw when compared to the grain: in the grain it was found to vary between $0.16-0.77 \mathrm{~g} \mathrm{~kg}^{-1}$ in 2017 and $0.17-0.37 \mathrm{~g} \mathrm{~kg}^{-1}$ in 2018 . Meanwhile, in straw $\mathrm{Ca}$ concentration was detected higher $2.08-2.88$ and $2.13-4.07 \mathrm{~g} \mathrm{~kg}^{-1}$, respectively.
When BA and BAG granules were used for fertilisation, $\mathrm{Ca}$ concentration in straw increased significantly in 2018. Finally, Mg concentration exhibited a statistically significant increase in grain in both 2017 and 2018 compared to the control. Only $\mathrm{Zn}$ and $\mathrm{Cd}$ concentrations were detected in spring barley grain in both experimental years. Plants had a higher $\mathrm{Zn}, \mathrm{Cd}$ and $\mathrm{Cu}$ content when using bulk BA as compared to BAG (Fig. 6). Ash granules do not act on the soil directly like bulk BA. As a result, plants fertilised with granules absorbed less heavy metals. 
$\mathrm{Zn}$ has definite value for physiology of living organisms. However, higher concentrations of this element accumulate in the soil and have a negative impact on plants. Relevant to this experiment is low soil acidity $(\mathrm{pH})$, where $\mathrm{Zn}$ solubility, spring barley grain and straw uptake and the resulting potential for $\mathrm{Zn}$ phytotoxicity increase (Brendova et al., 2016). The BA used in this pot experiment was alkaline. The $\mathrm{pH}$ was as high as $\sim 13$. In the second year of the experiment, $\mathrm{Zn}$ concentration in grain was higher (Fig. 6). Zn content in the grain cultivated in Lithuania is $19 \pm 5.2 \mathrm{mg} \mathrm{kg}^{-1}$ (Staugaitis et al., 2016). In our experiment, $\mathrm{Zn}$ concentration in the spring barley grain ranged within $4.58-22.5 \mathrm{mg} \mathrm{kg}^{-1}$. The highest $\mathrm{Zn}$ concentration in grain was determined using BA (20.2$22.5 \mathrm{mg} \mathrm{kg}^{-1}$ ) and BAG70 fertiliser (19.9-22.2 $\left.\mathrm{mg} \mathrm{kg}^{-1}\right)$. This trend was observed in both experimental years.

$\mathrm{Cd}$ is a highly toxic environmental pollutant (Peng et al., 2019). According to Commission Regulation (EC) No 1881/2006 of setting maximum levels for certain contaminants in foodstuffs (European Food Safety Authority, 2018), in grains Cd concentration allowed is $0.1 \mathrm{mg} \mathrm{kg}{ }^{-1}$. The overall increase of $\mathrm{Cd}$ concentration in each experimental year was up to $0.03 \mathrm{mg} \mathrm{kg}^{-1}$. Therefore, it is likely that the use of these fertilisers for several years in a row would increase the amount of $\mathrm{Cd}$ in the grains. The concentrations of microelements $\mathrm{Zn}$ and $\mathrm{Cu}$ were detected in spring barley straw (Fig. 6). The concentrations of potentially toxic heavy metals $\mathrm{Pb}, \mathrm{Ni}$ and $\mathrm{Cr}$ in spring barley grain and straw were below the detection level. Based on these results, in acidic soils higher rates of granulated ash can be used.

\section{Conclusions}

1. The results obtained in this research showed that in both experimental years the overall phosphorus (P) balance was negative in all treatments except for the one with biofuel ash (BA). While within the error margin, change of potassium $(\mathrm{K})$ concentration was also largely positive when using bulk BA and biofuel ash granules (BAG) but starkly negative under control treatment. Calcium $(\mathrm{Ca})$ and magnesium $(\mathrm{Mg})$ balance was positive in all the treatments except for the control. Optimal soil humidity is needed for the effective release of major nutrients $(\mathrm{K}, \mathrm{P}, \mathrm{Ca}$ and $\mathrm{Mg}$ ) from BAG, while excessive rain can increase their leaching.

2. Due to the high $\mathrm{Zn}$ and $\mathrm{Cu}$ content in ash, the concentrations of these microelements in the soil increased. Overall, the content of heavy metals and microelements increased linearly with the increase in the amount of BA in the granules; however, it did not exceed the permissible limits. Heavy metal contamination in the soil was also found to be higher with the use of bulk BA. The concentrations of cadmium $(\mathrm{Cd})$ and zinc $(\mathrm{Zn})$ were detected in spring barley grain, and $\mathrm{Zn}$ and $\mathrm{Cu}$ - in straw. The concentrations of potentially toxic heavy metals $\mathrm{Pb}$, $\mathrm{Ni}$ and $\mathrm{Cr}$ in spring barley grain and straw were below the detection level. Based on these results, higher rates of granulated ash can be used on acidic soils.

Received 18062020

Accepted 12102020

\section{References}

Adomaitis T., Staugaitis G., Mažvila J., Vaišvila Z., Arbačiauskas J., Lubytė J., Šumskis D., Švėgžda A. 2013. Leaching of base cations as affected by a forty-year use of mineral fertilisation. 7emdirhyste-Agriculture, 100 (2): 119-126. https://doi.org/10.13080/z-a.2013.100.015

Aissaoui H., Barkat D. 2018. Physico-chemical characterizations and impact of organic matter on the dynamics of heavy metals $(\mathrm{Cu}$, and $\mathrm{Zn})$ in some soils of Biskra (Algeria). Journal of King Sand Iniversity - Science 32 (1): 307-311. https://doi.org/10.1016/j.jksus.2018.05.016

Al-Homidy A. A., Dahim M. H., Abd El Aal A. K. 2017. Improvement of geotechnical properties of sabkha soil utilizing cement kiln dust. Journal of Rock Mechanics and Gentechnical Fngineering. 9 (4): 749-760 https://doi.org/10.1016/j.jrmge.2016.11.012

Arulrajah A., Mohammadinia A., D'Amico A., Horpibulsuk S. 2017. Cement kiln dust and fly ash blends as an alternative binder for the stabilization of demolition aggregates. Construction and Building Materials. 145: 218-225. https://doi.org/10.1016/j.conbuildmat.2017.04.007

Brendova K., Lemanova V., Pavlikova D., Ilustoš P. 2016. Utilization of biochar and activated carbon to reduce $\mathrm{Cd}$, $\mathrm{Pb}$ and $\mathrm{Zn}$ phytoavailability and phytotoxicity for plants. Iournal of Fnvironmental Management 181: 637-645. https://doi.org/10.1016/j.jenvman.2016.06.042

Bowden-Green B., Briens L. 2016. An investigation of drum granulation of hiochar nowder. Powder Technology. 288: 249-254. https://doi.org/10.1016/j.powtec.2015.10.046

Buneviciene K., Drapanauskaite D., Mazeika R., Tilvikiene V., Baltrusaitis J. 2020. Granulated biofuel ash as a sustainable source of nlant nutrients. Waste Management and Research. https://doi.org/10.1177/0734242X20948952

Cole J. C., Smith M. W., Penn C. J., Cheary B. S., Conaghan K. J. 2016. Nitrogen, phosphorus, calcium, and magnesium applied individually or as a slow release or controlled release fertilizer increase growth and yield and affect macronutrient and micronutrient concentration and content of field-grown tomato nlants. Scientia Horticulturae, 211: 420-430. https://doi.org/10.1016/j.scienta.2016.09.028

Dimkpa C. O., Bindraban P. S. 2016. Fortification of micronutrients for efficient agronomic production: a review. Agronomy for Sustainahle Develonment, 36 (1): 1-26. https://doi.org/10.1007/s13593-015-0346-6

Drapanauskaite D., Buneviciene K., Repsiene R., Mazeika R., Navea J., Baltrusaitis J. 2020. Physicochemical characterization of pelletized lime kiln dust as potential liming material for acidic soils. Waste and Binmass Valorization. https://doi.org/10.1007/s12649-020-01107-0

Dwivedi A., Jain M. K. 2014. Fly ash - waste management and overview: a review. Recent Research in Science and Technology, 6 (1): 30-35.

El-Attar M. M., Sadek D. M., Salah A. M. 2017. Recycling of high volumes of cement kiln dust in bricks industry. Journal of Cleaner Production, 143: 506-515 https://doi.org/10.1016/j.jclepro.2016.12.082

EPA. 1999. United States Environmental Protection Agency. Background report on fertilizer use, contaminants and regulations. USA, $395 \mathrm{p}$.

European Food Safety Authority. 2018. The 2016 European Union report on nesticide residues in fond. FFSA Inurnal, 16 (7): 1-139. https://doi.org/10.2903/j.efsa.2018.5348

Freire M., Lopes H., Tarelho L. A. C. 2015. Critical aspects of biomass ashes utilization in soils: Composition, leachability. PAH and PCDD/F. Waste Management 46: 304-315. https://doi.org/10.1016/j.wasman.2015.08.036

HN 60:2004. Pavojingu cheminių medžiagų didžiausios leidžiamos koncentracijos dirvožemyje. Lietuvos Respublikos sveikatos apsaugos ministerija, 12 p. (in Lithuanian).

Kafodya I., Okonta F. 2018. Effects of natural fiber inclusions and pre-compression on the strength properties of lime-fly ash stabilised soil. Construction and Building Materials, 170: 737-746 https://doi.org/10.1016/j.conbuildmat.2018.02.194

Kobayashi T., Nishizawa N. K. 2012. Iron uptake, translocation, and regulation in higher plants. Annual Review of Plant Biologv 63 (1): 131-152.

https://doi.org/10.1146/annurev-arplant-042811-105522 
Kryzevicius Z., Janusiene L., Karcauskiene D., Slepetiene A., Vilkiene M., Zukauskaite A. 2019. Aluminium leaching response to acid precipitation in a lime-affected soil. Zemdirbyste-Agriculture, 106 (4): 315-320. https://doi.org/10.13080/z-a.2019.106.040

Kuppusamy S., Thavamani P., Megharaj M., Venkateswarlu K., Naidu R. 2016. Agronomic and remedial benefits and risks of applying biochar to soil: current knowledge and future research directions. Environment International, 87: 1-12. https://doi.org/10.1016/j.envint.2015.10.018

Lamers F., Cremers M., Matschegg D., Schmidl C., Hannam K., Hazlett P., Madrali S., Dam B. P., Roberto R., Mager R., Davidsson K., Bech N., Feuerborn H.-J., Saraber A. 2018. Options for increased use of ash from biomass combustion and co-firing. IEA Bioenergy. Task 32: Biomass Combustion and Cofiring, $60 \mathrm{p}$.

Maschowski C., Zangna M. C., Trouve G., Giere R. 2016. Bottom ash of trees from Cameroon as fertilizer. Applied Geochemistrv. 72: 88-96.

https://doi.org/10.1016/j.apgeochem.2016.07.002

Masilionytè L., Maikštènienè S. 2016. The effect of alternative cropping systems on the changes of the main nutritional elements in the soil. Zemdirbyste-Agriculture, 103 (1): 3-10. https://doi.org/10.13080/z-a.2016.103.001

Muhammad N., Zvobgo G., Zhang G. P. 2019. A review: the beneficial effects and possible mechanisms of aluminum on plant growth in acidic soil. Journal of Integrative Agriculture. 18 (7): 1518-1528.

https://doi.org/10.1016/S2095-3119(18)61991-4

Patra K. C., Rautray T. R., Nayak P. 2012. Analysis of grains grown on fly ash treated soils. Applied Radiation and Isotones, 70 (8): 1797-1802. https://doi.org/10.1016/j.apradiso.2012.03.037

Peng L., Chen J., Chen L., Cai J., Ding W., Gao Y., Wu Y., Cheng S. 2019. Physicochemical characterization of a novel cadmium-binding protein from rice grain endosperm. Journal of Cereal Science, 90: 1-6. https://doi.org/10.1016/j.jcs.2019.10282

Pesonen J., Kuokkanen T., Rautio P., Lassi U. 2017. Bioavailability of nutrients and harmful elements in ash fertilizers: effect of granulation. Biomass and Bioenergy, 100: 92-97. https://doi.org/10.1016/j.biombioe.2017.03.019
Pujilestari E. S., Hudiyono S., Moersidik S. S. 2017. Environmental impact of metals leaching generated from long term coal ash disposal placement of more than 10 years periods. Asian Journal of Applied Sciences, 5 (6): 1116-1122.

Rasmusson H., Sarenbo S., Claesson T. 2013. Ash products and their economic profitability. The Open Waste Management Inurnal 6: 1-5.

https://doi.org/10.2174/1876400201306010001

Rodriguez Y., Maudier B., Zagal E., Hernandez P. 2019. Effects of wood ash on nutrients and heavy metal(oid)s mobility in an ultisol. Fnviromental Research and Public Health, 16 (7): 1246. https://doi.org/10.3390/ijerph16071246

Soares J. C., Santos C. S., Carvalho S. M. P., Pintado M. M., Vasconcelos M. W. 2019. Preserving the nutritional quality of crop plants under a changing climate: importance and strategies. Plant and Soil. $443(1-26)$.

https://doi.org/10.1007/s11104-019-04229-0

Staugaitis G., Narutyte I., Arbačauskas J., Vaišvila Z., Rainys K., Mažeika R., Masevičienè A., Žičkienè L., Šumskis D. 2016. The influence of composts on yield and chemical elements of winter wheat and spring barley. ZemdirbysteAgriculture, 103 (4): $355-362$ https://doi.org/10.13080/z-a.2016.103.045

Vaatainen K., Sirparanta E., Raisanen M., Tahvanainen T. 2011. The costs and profitability of using granulated wood ash as a forest fertilizer in drained peatland forests. Biomass and Binenergy, 35 (8): 3335-3341.

https://doi.org/10.1016/j.biombioe.2010.09.006

Vassilev S. V., Baxter D., Andersen L. K., Vassileva C. G. 2013. An overview of the composition and application of biomass ash. Part 2. Potential utilisation, technological and ecolngical advantages and challenges. Fuel, 105: 19-39. https://doi.org/10.1016/j.fuel.2012.10.001

WRB. 2014. World reference base for soil resources. World Soil Resources Reports No. 106. FAO, 189 p.

Yao Q., Samad N. B., Keller B., Seah X. S., Huang L., Lau R. 2014. Mobility of heavy metals and rare earth elements in incineration bottom ash through particle size reduction. Chemical Fngineering Science, 118: 214-220. https://doi.org/10.1016/j.ces.2014.07.013

\title{
Biokuro pelenų granulès - dirvožemio ir augalų maisto medžiagų šaltinis
}

\author{
K. Bunevičienè, D. Drapanauskaitė, R. Mažeika, V. Tilvikienè \\ Lietuvos agrarinių ir miškų mokslų centras
}

\begin{abstract}
Santrauka
Siekiant tvariai naudoti bioenergetikos atliekas, didelę reikšmę turi biokuro pelenuose esantis maisto medžiagų kiekis. Tyrimo metu granuliuotos trąšos buvo pagamintos iš biokuro pelenų, kalkių krosnies dulkių ir vandens. Eksperimento metu buvo nustatyta birių pelenų, kalkių krosnies dulkių ir pagamintų granulių cheminè sudètis. Vegetacinis eksperimentas vykdytas atviroje tyrimų aikštelèje. Tyrimu siekta ịvertinti maisto medžiagų ịsisavinimą vasarinių miežiu grūduose ir šiauduose panaudojus pelenų granules.

Tyrimo rezultatai parodè, kad panaudojus granuliuotus pelenus $2018 \mathrm{~m}$. vasarinių miežių šiauduose nustatytas suminio kalio kiekio padidèjimas $\left(21,5-28,0 \mathrm{~g} \mathrm{~kg}^{-1}\right), \mathrm{o} 2017 \mathrm{~m}$. jo kiekis reikšmingai nepakito. Kalcio koncentracija reikšmingai padidèjo šiauduose antraisiais tyrimo metais. Sunkiujų metalų $(\mathrm{Cd}, \mathrm{Pb}, \mathrm{Ni}$ ir $\mathrm{Cr})$ kiekio reikšmingu pokyčių dirvožemyje nenustatyta - jų koncentracijos neviršijo leistinų normų. Dèl didelio Zn ir Cu kiekio pelenuose padidejo šių mikroelementų koncentracija dirvožemyje. Sunkiụjų metalų ir mikroelementų kiekis tiesiškai didèjo priklausomai nuo biokuro kiekio granulèse. Vasarinių miežių grūduose buvo aptikta $\mathrm{Cd}\left(0,003-0,030 \mathrm{mg} \mathrm{kg}^{-1}\right)$ ir $\mathrm{Zn}\left(4,58-22,5 \mathrm{mg} \mathrm{kg}^{-1}\right)$, šiauduose $-\mathrm{Zn}$ ir $\mathrm{Cu}$.
\end{abstract}

Reikšminiai žodžiai: biokuras, pelenų granulès, kalkių krosnies dulkès, maisto medžiagos, sunkieji metalai. 